\title{
CRESER O MAUSOLO DANDO “CARTILLA” SOBRE SOCIALIZACION HUMANA. José Muñoz Martínez.
}

Este libro, cartilla o simplemente escrito conduce al lector por los caminos del humor y la ironía a la reflexión sobre su propia infancia y su quehacer como maestro de otros en su relación necesaria con otros congéneres, máxime si éstos son sus hijos o sus alumnos.

Todos somos maestros y por tanto todos aprendemos y enseñarnos en el diario vivir; sin embargo, pocas veces tenemos oportunidad de sentarnos horas enteras, un lápiz en mano a pensar sobre nuestra vida, nuestra educación, nuestra cultura o nuestros hijos. Con maestría y agudeza Mausolo introduce su dedo índice inflamado en la llaga de nuestra realidad escolar, el aula, la calle, el hogar, la iglesia, el parque, la panadería o la carnicería y con sus reflexiones personales nos incita a que elaboremos y reflexionemos sobre todo y ante todo para transformar, para cambiar, para iniciar cada día una nueva vida.

Está a la venta en la Facultad de Educación de la U.P.N. Bogotá, Calle 72 No. 11-86 Teléfono 2352044 Ext. 123. 